\title{
Effects of short- and long-term feeding of zinc oxide-supplemented diets on the mature, female domestic fowl with special reference to tissue mineral content
}

\author{
BY N. JACKSON ${ }^{1,2}$, S. W. GIBSON² AND M. H. STEVENSON ${ }^{1,2}$ \\ ${ }^{1}$ Agricultural and Food Chemistry Research Division, Department of Agriculture \\ for Northern Ireland, and 'The Queen's University of Belfast, \\ Newforge Lane, Belfast BT9 5PX
}

(Received 12 August 1985 - Accepted 16 September 1985)

\footnotetext{
1. In Expt 1, the effects on laying hens of diets supplemented with zinc oxide providing up to $20 \mathrm{~g}$ added zinc $/ \mathrm{kg}$ were compared. In Expt 2 the diets contained up to $6 \mathrm{~g}$ added $\mathrm{Zn} / \mathrm{kg}$.

2 . In both experiments, food intake, body-weight, egg number, and liver, oviduct and ovary weights $/ \mathrm{kg}$ body-weight were significantly reduced by added $\mathrm{ZnO}$; gizzard weight $/ \mathrm{kg}$ body-weight was significantly increased. In Expt 2, pancreas weight was significantly reduced by added $\mathrm{ZnO}$.

3. Liver, kidney and pancreatic $\mathrm{Zn}$ and iron concentrations were significantly elevated in both experiments.

4. In both experiments, liver, kidneys and pancreatic copper concentrations gave quadratic responses to added $\mathrm{ZnO}$.
}

Zinc toxicity is not normally a problem encountered with domestic animals. It has been established that pigs (Cox \& Hale, 1962), rats (Magee \& Spahr, 1964), cattle (Miller et al. 1965) and sheep (Ott et al. 1966a) exhibit considerable tolerance to high dietary concentrations of $\mathrm{Zn}$ compounds. Several reports have confirmed that the performance of broiler fowl is not adversely affected by the dietary inclusion of zinc oxide to provide up to $1 \mathrm{~g} \mathrm{Zn/kg} \mathrm{diet} \mathrm{(Roberson} \mathrm{\&} \mathrm{Schaible,} \mathrm{1960;} \mathrm{Johnson} \mathrm{et} \mathrm{al.} \mathrm{1962;} \mathrm{Kincaid} \mathrm{et} \mathrm{al.} \mathrm{1976} \mathrm{b).}$

Although the supplementation of diets with excessive levels of $\mathrm{Zn}$ compounds has been suggested as a method for the induction of a resting phase for laying hens (Creger \& Scott, 1977; Shippee et al. 1979), there is relatively little information available concerning the effects of offering adult hens diets containing high levels of $\mathrm{Zn}$ compounds. In the mature, female domestic fowl, Hermayer et al. (1977) and Palafox \& Ho-A (1980) demonstrated that the dietary inclusion of $\mathrm{Zn}$ compounds, at levels providing up to 10 and $20 \mathrm{~g} \mathrm{Zn} / \mathrm{kg}$ diet respectively, caused a severe depression in food consumption, egg production and body-weight. More recently, Gentle et al. (1982) identified a threshold level of $\mathrm{ZnO}$ addition at or above $6 \mathrm{~g} \mathrm{Zn} / \mathrm{kg}$ diet which produced a rapid reduction in the food intake of adult hens.

Dietary addition of excessive amounts of $\mathrm{Zn}$ compounds to diets being consumed by broiler chicks has been shown to cause a marked increase in liver $\mathrm{Zn}$ concentration (Johnson et al. 1962; Kincaid et al. 1976 b) and in the pancreatic tissue Zn concentration of cockerels (Eltohamy et al. 1980). Studies on the specific effects of high dietary levels of $\mathrm{ZnO}$ on the storage of tissue $\mathrm{Zn}$ in mature domestic fowl have been very limited and preliminary investigations, both short- and long-term, into the effects of high dietary levels of $\mathrm{ZnO}$ on both the performance and tissue mineral accumulation of laying hens were therefore initiated.

\section{MATERIALS AND METHODS}

Expt 1

Seventy-two Hisex laying hens (thirty-six white; thirty-six brown), 40 weeks of age, were placed in galvanized iron cages fitted with individual feeder troughs and nipple drinkers. 
Table 1. Composition $(\mathrm{g} / \mathrm{kg})$ and analysis of the control diet as fed

\begin{tabular}{|c|c|}
\hline \multicolumn{2}{|c|}{ Composition $(\mathrm{g} / \mathrm{kg})$} \\
\hline Ground maize & $600 \cdot 0$ \\
\hline Ground wheat & $74 \cdot 2$ \\
\hline Soya-bean-meal extract $(431 \mathrm{~g} \mathrm{CP} / \mathrm{kg})$ & 187.5 \\
\hline White fish meal $(623 \mathrm{~g} \mathrm{CP} / \mathrm{kg})$ & $26 \cdot 1$ \\
\hline Dried grass meal $(158 \mathrm{~g} \mathrm{CP} / \mathrm{kg})$ & $25 \cdot 0$ \\
\hline Limestone flour & 71.9 \\
\hline Dicalcium phosphate & $9 \cdot 8$ \\
\hline Sodium chloride & $3 \cdot 0$ \\
\hline Vitamin-mineral supplement* & $2 \cdot 5$ \\
\hline & $1000 \cdot 0$ \\
\hline \multicolumn{2}{|c|}{ Analysis as fed $(/ \mathrm{kg})$} \\
\hline Dry matter (g) & $982 \cdot 0$ \\
\hline Metabolizable energy $(\mathrm{MJ}) \dagger$ & 11.0 \\
\hline $\mathrm{CP}(\mathrm{g})$ & 159.9 \\
\hline Diethyl ether extract $(\mathrm{g})$ & $25 \cdot 1$ \\
\hline Ash (g) & $109 \cdot 0$ \\
\hline Calcium (g) & $29 \cdot 5$ \\
\hline Phosphorus (g) & $5 \cdot 8$ \\
\hline Zinc $(\mathrm{mg})$ & $56 \cdot 0$ \\
\hline Iron (mg) & $361 \cdot 0$ \\
\hline Copper (mg) & $6 \cdot 0$ \\
\hline
\end{tabular}

$\mathrm{CP}$, crude protein (nitrogen $\times 6 \cdot 25$ ).

* Provided ( $/ \mathrm{kg} \mathrm{diet}$ ): $1.76 \mathrm{mg}$ retinol, $35 \mu \mathrm{g}$ cholecalciferol, $2.9 \mathrm{mg}$ riboflavin, $4.9 \mu \mathrm{g}$ cyanocobalamin, $5.8 \mathrm{mg}$ $\alpha$-tocopherol, $0.7 \mathrm{mg}$ menadione sodium bisulphite, $10 \mathrm{mg}$ nicotinic acid, $5.8 \mathrm{mg}$ calcium $\mathrm{D}$-pantothenate, $200 \mathrm{mg}$ choline chloride, $1.5 \mathrm{mg}$ potassium iodide, $14.4 \mathrm{mg} \mathrm{Fe}, 0.1 \mathrm{mg}$ selenium, $2.0 \mathrm{mg}$ cobalt, $7.2 \mathrm{mg}$ manganese, $\mathrm{Zn}$-free and $\mathrm{Cu}$-free.

+ Calculated.

The poultry house was unheated, the maximum and minimum temperatures being $14^{\circ}$ and $4^{\circ}$ respectively. A lighting regimen of $17 \mathrm{~h}$ light $-7 \mathrm{~h}$ dark was maintained during the experiment. The birds were randomly allocated to one of six treatment groups, each comprising six birds of each hybrid strain. The diets, offered ad lib. for 3 weeks, were the control diet (Table 1), and this diet supplemented with 4, 8, 12, 16 and $20 \mathrm{~g} \mathrm{Zn}$ as finely-powdered $\mathrm{ZnO} / \mathrm{kg}$.

The birds were weighed initially and subsequently body-weight and food consumption recorded weekly and egg number daily. The eggs laid on $2 \mathrm{~d} /$ week were weighed. The birds given diets with $20 \mathrm{~g}$ added $\mathrm{Zn} / \mathrm{kg}$ were removed from the experiment at $10 \mathrm{~d}$ because food intake was severely depressed. After 3 weeks the birds were killed by decapitation.

The gizzard, oviduct and ovary were weighed, and liver, kidneys, pancreas, spleen and adrenals weighed and retained for dry matter, $\mathrm{Zn}$, iron and copper determinations. Tissue mineral concentrations were determined by atomic absorption spectrophotometry subsequent to dry ashing and solution in hydrochloric acid. Liver lipid concentrations were assayed on dried samples (Folch et al. 1957).

Before weighing, the gizzards were cut open, washed and the koilin layer examined to determine the gross effects of dietary treatment. Tissue samples were removed from the previously-weighed liver and kidneys of two birds taken at random from the control treatment, and of two birds from the highest dietary $\mathrm{Zn}$ treatment. The samples were then preserved in buffered neutral formalin $(100 \mathrm{ml} / \mathrm{l})$ and examined histopathologically.

The results were subjected to analysis of variance, log transformations being carried out for those variables which exhibited variance heterogeneity. 


\section{Expt 2}

Ninety-eight Hisex laying hens (forty-nine white; forty-nine brown), 40 weeks of age, were housed as in Expt 1 . The maximum and minimum temperatures were $18^{\circ}$ and $2^{\circ}$ respectively. They were randomly allocated to one of seven treatment groups each containing seven birds of each hybrid strain. Diets, offered ad lib. for five consecutive $28 \mathrm{~d}$ periods, consisted of the control diet, as used in Expt 1 (Table 1), and this diet supplemented with 1, 2, 3, 4, 5 and $6 \mathrm{~g} \mathrm{Zn}$ as $\mathrm{ZnO} / \mathrm{kg}$.

Body-weights were determined initially and at the end of each period. Food consumption was measured for each period. Daily records were made of egg production and eggs were weighed on $2 \mathrm{~d}$ /week. At the end of the experiment four birds of each strain were randomly selected from each treatment and killed by decapitation.

Specific organs were removed, weighed and analysed for mineral concentrations. Liver lipid concentration was determined as for Expt 1. Liver, kidney and gizzard samples were selected at random from two control birds and from two receiving the highest level of added dietary $\mathrm{ZnO}$. They were preserved in buffered neutral formalin and subsequently given an histopathological examination. Statistical analyses were carried out as for Expt 1.

\section{RESULTS \\ Expt 1}

No birds died during the experiment although this would possibly not have been the case if the birds on the highest level of $\mathrm{ZnO}$ supplementation had not been removed from the experiment after $10 \mathrm{~d}$. Feather loss, although not excessive, was apparent for the birds offered diets with 12-20 g added $\mathrm{Zn} / \mathrm{kg}$; breed differences were not evident. Damage of the gizzard lining, including erosion and rupture, was observed in approximately $20 \%$ of the birds given $16 \mathrm{~g}$ supplemental dietary $\mathrm{Zn}$ as $\mathrm{ZnO} / \mathrm{kg}$.

Mean weekly food and total $\mathrm{Zn}$ intakes, initial and final body-weights and weekly egg production are given in Table 2 . Mean weekly food intake, body-weights and egg numbers were highly significantly depressed by the dietary inclusion of $\mathrm{ZnO}$. The maximum $\mathrm{ZnO}$ intake occurred at the 4 and $8 \mathrm{~g} / \mathrm{kg}$ level of addition for the brown and white strains respectively.

During weeks 2 and 3 food consumption was significantly lower for the brown than for the white birds. In the final week the food intakes of the white and brown hens offered the diet providing $16 \mathrm{~g} \mathrm{Zn} / \mathrm{kg}$ were reduced to 9 and $2 \%$ of their respective controls.

Egg production had ceased by the end of the 1 st week for birds on the $12-20 \mathrm{~g} \mathrm{Zn} / \mathrm{kg}$ treatments and by the end of the 2 nd week for hens on the $8 \mathrm{~g} \mathrm{Zn} / \mathrm{kg}$ treatment. Even $4 \mathrm{~g}$ added $\mathrm{Zn} / \mathrm{kg}$ diet induced an almost complete pause in lay for both breeds by the 2 nd week.

Tissue weights $/ \mathrm{kg}$ body-weight together with liver lipid values are given in Table 3 . The tissues investigated, with the exception of kidneys and pancreas, showed a response to dietary treatment. The liver fresh weight and the oviduct and ovary weights showed decreasing responses, the mean weights for the oviduct and ovary being minimum at the $8 \mathrm{~g}$ added $\mathrm{Zn} / \mathrm{kg}$ diet. Gizzard weight $/ \mathrm{kg}$ body-weight showed an increasing response to $\mathrm{ZnO}$ supplementation. The liver lipid concentrations and total contents were significantly decreased by added $\mathrm{ZnO}$.

Results of the tissue $\mathrm{Zn}, \mathrm{Fe}$ and $\mathrm{Cu}$ analyses are presented in Tables 4-6 respectively. Dietary inclusion of $\mathrm{ZnO}$ significantly increased both $\mathrm{Zn}$ concentrations and total contents (Table 4) of all the tissues examined except in the case of the adrenal glands.

The liver Fe concentrations and contents (Table 5) were increased up to 400 and $200 \%$ respectively of the control group by dietary treatment while for kidneys the Fe concentration 





Effects of dietary $\mathrm{ZnO}$ in the laying hen

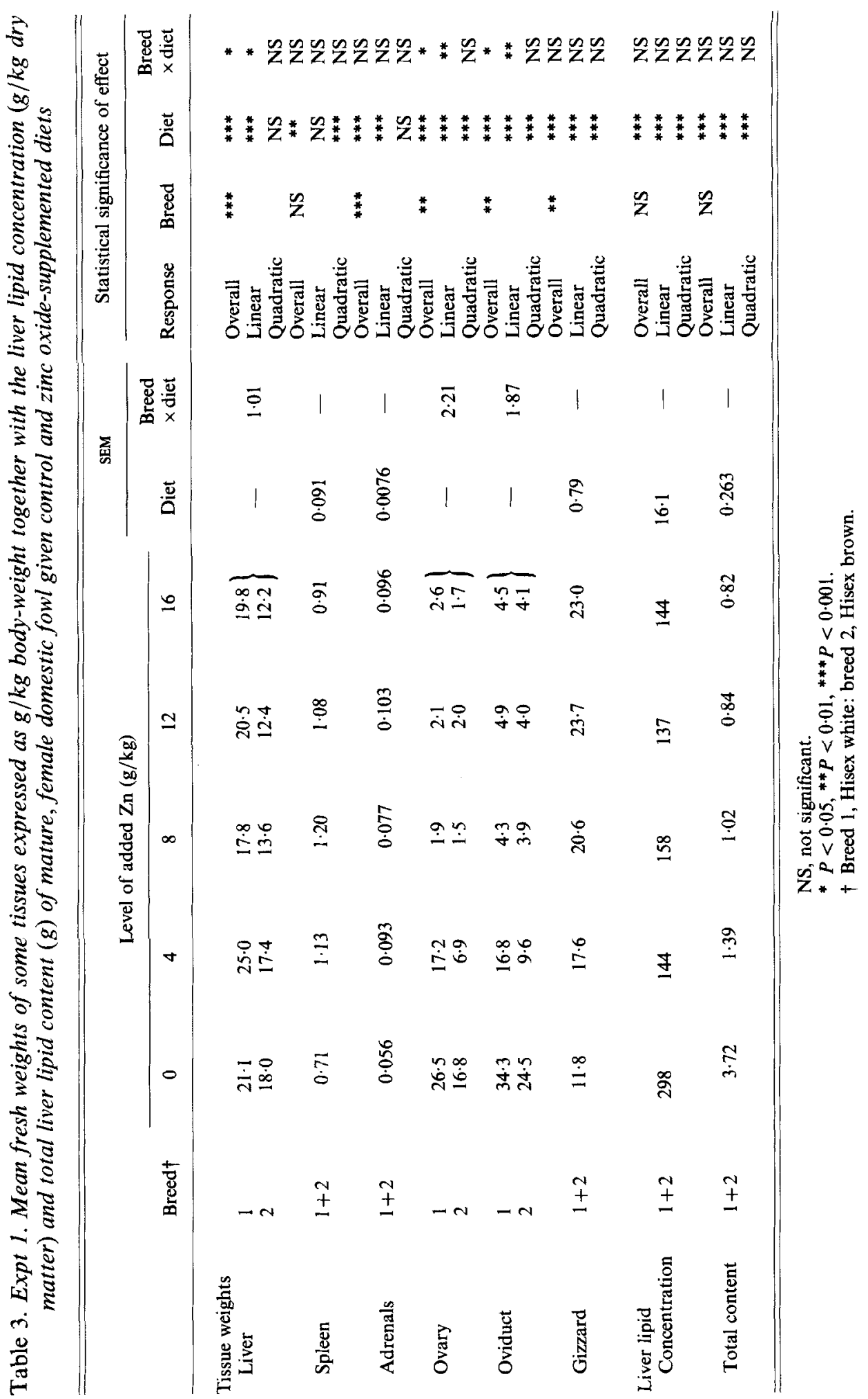


Effects of dietary $\mathrm{ZnO}$ in the laying hen

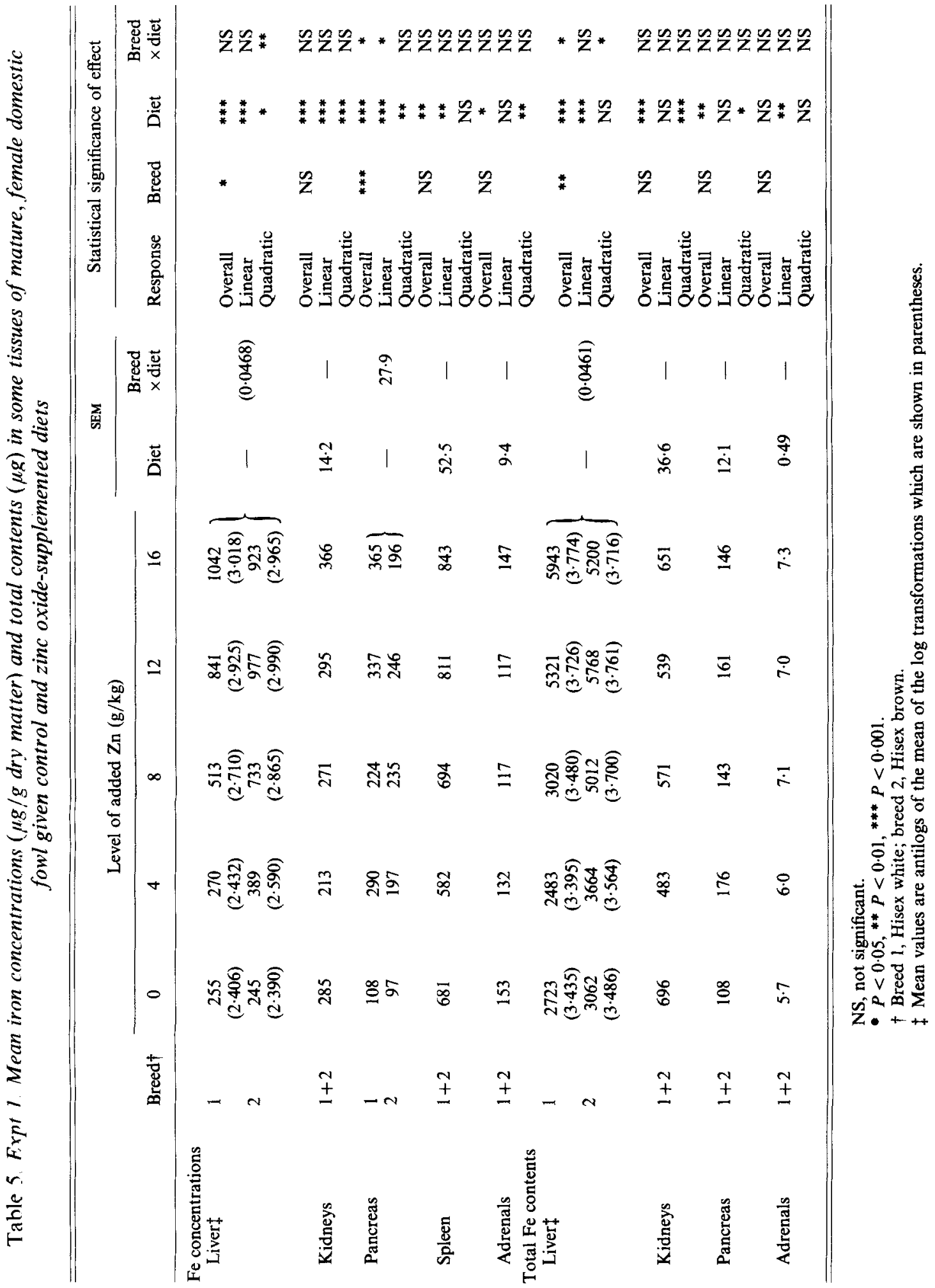




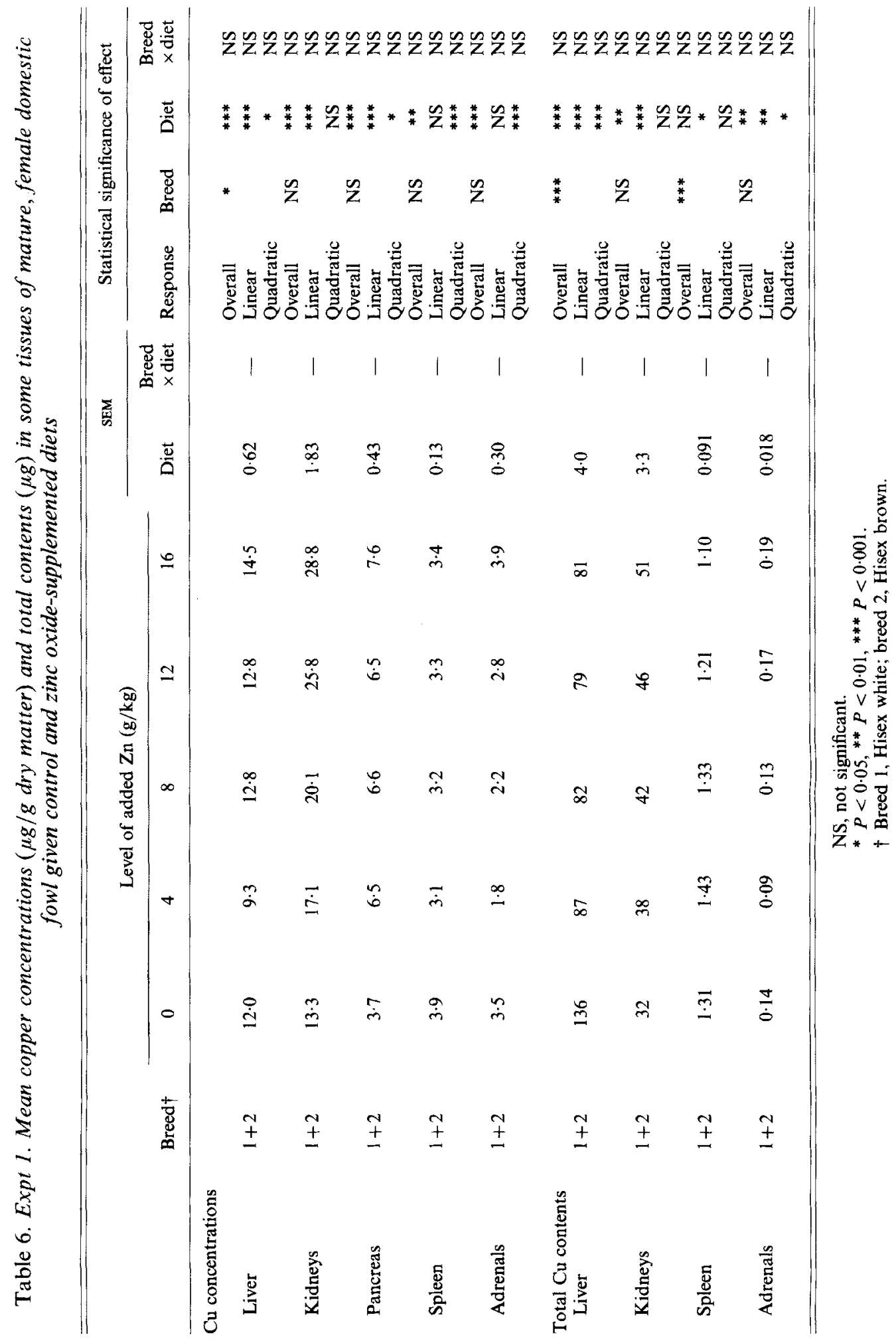


increased to $128 \%$ of the control value and total $\mathrm{Fe}$ content decreased by a maximum of $23 \%$. The pancreas also showed a marked increase in Fe concentration and content.

Liver, pancreas, spleen and adrenals $\mathrm{Cu}$ concentrations (Table 6) exhibited a quadratic response and renal $\mathrm{Cu}$ concentrations showed a positive linear response. Total $\mathrm{Cu}$ content of the liver gave a decreasing quadratic response to dietary added $\mathrm{ZnO}$ whereas total content of the kidneys showed a positive linear response. Total pancreatic $\mathrm{Cu}$ (results not presented) was unaffected by treatment, the mean for the white and brown birds being 3.6 and 4.9 $\mu \mathrm{g} / \mathrm{g}$ dry matter respectively.

\section{Expt 2}

The mortality rates of the birds offered diets containing 5 or $6 \mathrm{~g}$ added $\mathrm{Zn} / \mathrm{kg}$ were 56 and $86 \%$ respectively. Consequently information concerning the mean performance and tissue mineral analysis of the birds on the highest level of dietary $\mathrm{ZnO}$ has been omitted from the results. Mild changes were observed in the gizzards of the white hens with small erosions apparent, particularly in the troughs of the rugae of the gizzard linings. More distinctive changes were observed in the gizzards of the brown strain including haemorrhages of the koilin layer and dilatation of the mucosal glands.

$\mathrm{Zn}$ intakes (Table 7) showed an increasing quadratic response. Mean food intakes, body-weights, egg production and food conversion efficiencies (Table 7) were significantly depressed by addition of $\mathrm{ZnO}$. Mean food consumptions of the birds on the highest level of added $\mathrm{ZnO}$ were reduced by $64 \%$ compared with the controls and there was a negative linear relation between final body-weight and increasing dietary $\mathrm{Zn}$ concentration.

An almost complete pause in egg production was induced by 4 and $5 \mathrm{~g}$ added $\mathrm{Zn} / \mathrm{kg}$ diet and significant linear reductions in egg number, total egg weight and food conversion efficiency were apparent in response to the rise in dietary $\mathrm{ZnO}$.

The effects of dietary $\mathrm{ZnO}$ incorporation on the fresh weights of organs, expressed per unit body-weight, together with the liver lipid values are shown in Table 8. Significant overall dietary effects on liver, pancreas, gizzard, ovary and oviduct fresh weights $/ \mathrm{kg}$ body-weight were observed. Liver lipid concentration and total content were significantly reduced by increasing added $\mathrm{ZnO}$.

Results of the analyses of tissue $\mathrm{Zn}, \mathrm{Fe}$ and $\mathrm{Cu}$ concentrations and total contents are shown in Tables 9-11 respectively. The liver and pancreatic $\mathrm{Zn}$ concentrations and total contents exhibited significant increasing quadratic responses to dietary $\mathrm{ZnO}$ levels, while kidney and spleen concentrations and kidney total $\mathrm{Zn}$ showed increasing linear responses.

The liver $\mathrm{Fe}$ concentrations and contents increased by up to $200 \%$ at the highest level of $\mathrm{Zn}$ addition for the white birds. In contrast, there was a decrease at the intermediate levels of addition of about $50 \%$ for both strains. Kidney Fe concentrations and contents were depressed by $\mathrm{ZnO}$ treatments except at the $1 \mathrm{~g} / \mathrm{kg}$ level of addition.

The $\mathrm{Cu}$ concentrations and total contents of the liver were both significantly reduced by dietary treatment. The $\mathrm{Cu}$ concentrations of the kidneys and pancreas showed quadratic relations to dietary treatment. Negative linear responses were observed for the $\mathrm{Cu}$ concentration and total content of the spleen.

\section{DISCUSSION}

The results confirm previous evidence (Creger \& Scott, 1977; Shippee et al. 1979) that high dietary levels of $\mathrm{ZnO}$ can be used to induce a pause in lay by the mature, female domestic fowl.

Although Shippee et al. (1979) advocated the use of $10 \mathrm{~g} \mathrm{Zn}$ as $\mathrm{ZnO} / \mathrm{kg}$ diet, it is evident from Expt 1 that the addition of between 4 and $8 \mathrm{~g} \mathrm{Zn}$ as $\mathrm{ZnO} / \mathrm{kg}$ diet is sufficient to ensure 
Effects of dietary $\mathrm{ZnO}$ in the laying hen

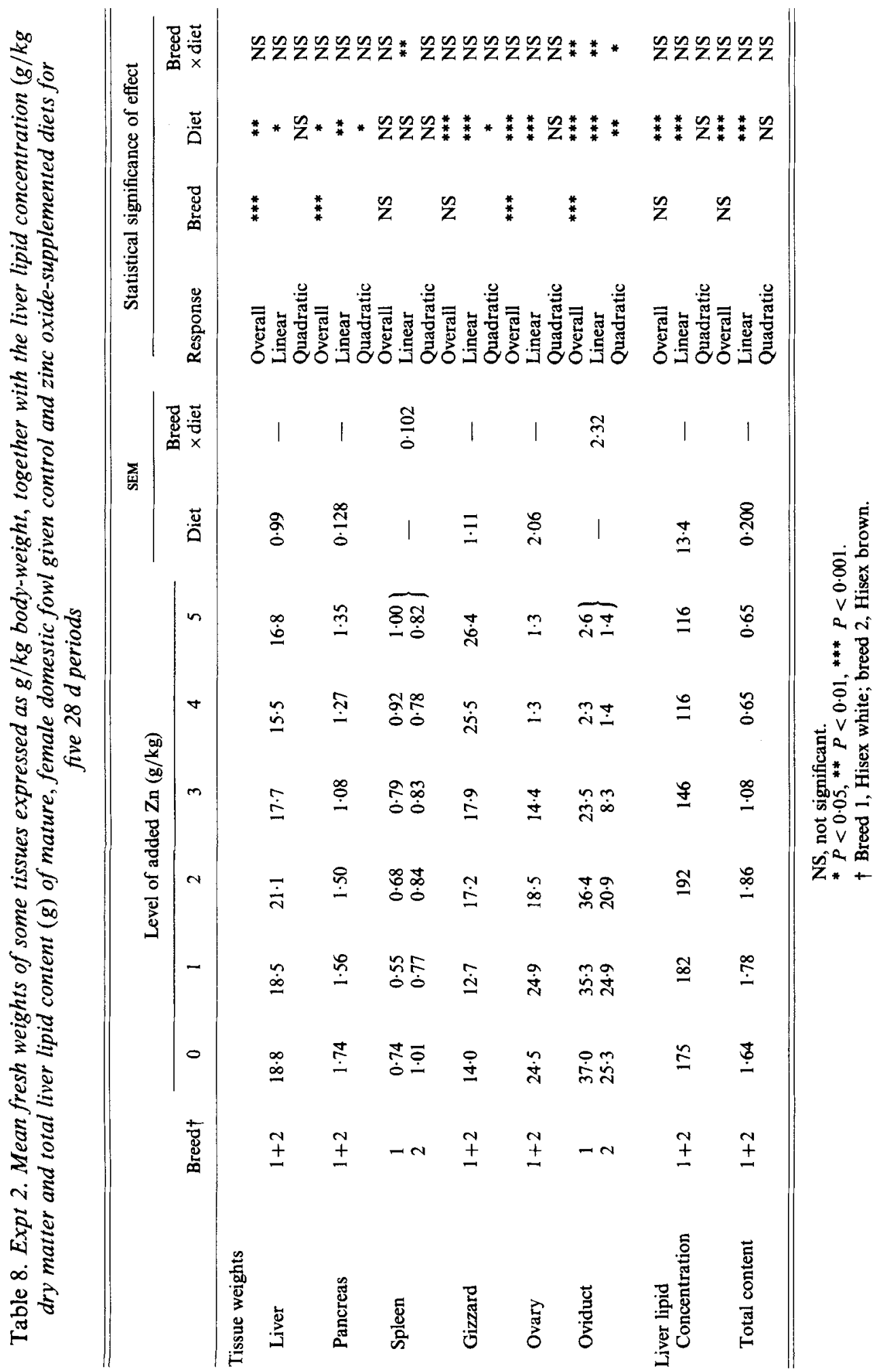


N. JACKSon, S. W. Gibson and M. H. STEvenson

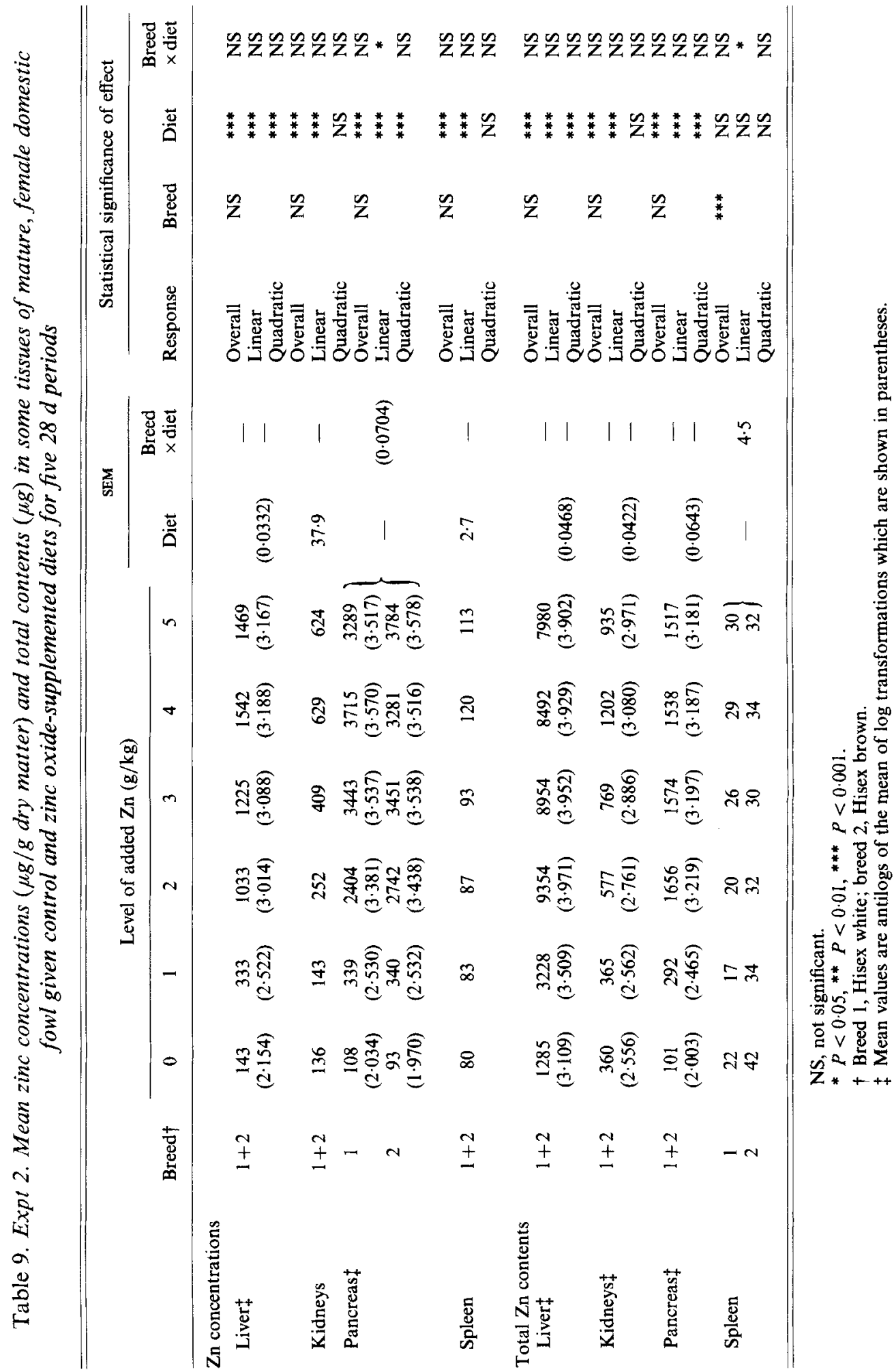


Effects of dietary $\mathrm{ZnO}$ in the laying hen




a rapid cessation in egg production and act effectively as a technique for the force-resting of laying hens.

The relatively high degree of tolerance of adult hens to excessive levels of dietary $\mathrm{Zn}$ compounds over an extended period of time was clearly demonstrated by Expt 2 which indicated that food consumption, body-weight and egg production over a 5-month period were not significantly affected by the dietary incorporation of up to $1 \mathrm{~g} \mathrm{Zn}$ as $\mathrm{ZnO} / \mathrm{kg}$. These observations corroborated those of Hermayer et al. (1977) who reported similar results.

The severe depression of food intake at dietary levels of $\mathrm{ZnO}$ addition in excess of $1 \mathrm{~g} \mathrm{Zn} / \mathrm{kg}$ diet presumably contributed to the corresponding reductions in body-weight and egg numbers, since the intakes of major and minor nutrients were well below the specific requirements recommended by the Agricultural Research Council (1975) for maintenance and adequate production. However, it is not clear whether the resultant loss in appetite associated with high dietary levels of $\mathrm{ZnO}$ may be attributed to toxic effects of the compound or to a reduction in palatability. The domestic fowl has been reported to have relatively few taste buds (Kare \& Rogers, 1976) and, in view of the organoleptic nature of $\mathrm{ZnO}$, it would seem that factors other than just a decrease in palatability have, at least partially, induced inappetance. Dewar et al. (1983) have identified gizzard and pancreatic lesions occurring in hens offered $10 \mathrm{~g} \mathrm{Zn}$ as $\mathrm{ZnO} / \mathrm{kg}$ diet for $4 \mathrm{~d}$, and it is possible that these toxic effects may be injurious to the general health and consequently to the appetite of the bird.

In the short-term experiment (Expt 1), further reductions in body-weight were not substantially induced by dietary addition of $\mathrm{ZnO}$ at levels providing more than $8 \mathrm{~g} \mathrm{Zn} / \mathrm{kg}$ diet. Examination of the fresh weights of the liver, pancreas and reproductive organs per unit body-weight also revealed that they were not significantly further depressed by higher dietary levels of added $\mathrm{ZnO}$ despite associated reductions in food intake. However, it should also be noted that $\mathrm{Zn}$ intake per unit body-weight was maximum for the brown strain at $4 \mathrm{~g}$ added $\mathrm{Zn} / \mathrm{kg}$ diet while for the white strain the maximum was above $8 \mathrm{~g}$ added $\mathrm{Zn} / \mathrm{kg}$. It appears that offering laying hens a diet containing approximately $8 \mathrm{~g} \mathrm{Zn} / \mathrm{kg}$ for at least $7 \mathrm{~d}$ is sufficient to cause a complete regression in the ovary and oviduct tissues. In the fowl the liver is the principal site of fatty acid synthesis (Leveille, 1969). Thus, a considerable proportion of the decrease in liver fresh weight may be attributed to the depression of oestrogen production and the consequent inhibition of oestrogen-induced lipidaemia (Griminger, 1976). Furthermore, the decrease in liver weight was similar in magnitude to the increase in hepatic weight observed when immature pullets came into lay (Pearce, 1971).

The marked increase in gizzard weight in response to dietary $\mathrm{ZnO}$ addition is rather similar to the effects observed on supplementing diets with high levels of copper sulphate (Fisher et al. 1973; Stevenson \& Jackson, 1981).

Brake et al. (1977) suggested that increases in adrenal gland and spleen weight of force-moulted birds were indicative of physiological stress, at least during the early phase of starvation, while Eltohamy et al. (1980) identified hypertrophy of the adrenal cortex in cockerels offered up to $4 \mathrm{~g} \mathrm{Zn} / \mathrm{kg}$ diet and hypothesized that excessive dietary $\mathrm{Zn}$ indirectly affected the release of adrenocorticotrophic hormone from the amphophils of the cephalic lobe. This suggests that the increased weights of the adrenals and spleen per unit body-weight may possibly have been induced by stress effects, thus reducing food consumption.

The increase in hepatic and renal $\mathrm{Zn}$ concentration with increasing dietary level of $\mathrm{ZnO}$ addition supports the findings of Johnson et al. (1962) and Kincaid et al. (1976b) who reported elevated $\mathrm{Zn}$ concentrations in both the liver and kidneys of broiler chicks given diets incorporating $\mathrm{ZnO}$ at levels of 2 and $2.4 \mathrm{~g} \mathrm{Zn} / \mathrm{kg}$ diet respectively.

The highest concentration of $\mathrm{Zn}$ was found in the pancreas, increasing by 500 -fold in hens offered $4 \mathrm{~g} \mathrm{Zn}$ as $\mathrm{ZnO} / \mathrm{kg}$ diet. This substantiates the observation by Oh et al. (1979) that $\mathrm{Zn}$ accumulated to the largest extent in the metallothionein of pancreatic tissue in 
broiler chicks offered excess dietary $\mathrm{Zn}$ acetate. Marked increases in pancreatic $\mathrm{Zn}$ have also been reported in cockerels (Eltohamy et al. 1980), sheep (Ott et al. 1966a) and calves (Kincaid et al. 1976a) given high levels of $\mathrm{Zn}$ compounds.

It is apparent from the present findings that the accumulation of tissue $\mathrm{Zn}$ in the fowl exhibits a threshold level of tolerance to the concentration of dietary $\mathrm{ZnO}$. The results of Expt 2 indicate that the threshold for mature hens given $\mathrm{ZnO}$-supplemented diets is at a level of about $1 \mathrm{~g} \mathrm{Zn} / \mathrm{kg}$ diet. Although at this level of inclusion the $\mathrm{Zn}$ concentrations of both liver and pancreas were observed to increase more than twofold compared with the controls, the effect of $2 \mathrm{~g}$ added $\mathrm{Zn}$ as $\mathrm{ZnO} / \mathrm{kg}$ diet was to increase their $\mathrm{Zn}$ concentrations by over seven- and twenty-five-fold respectively. Thresholds of dietary $\mathrm{Zn}$ compound concentrations above which tissue $\mathrm{Zn}$ accumulation increases markedly have also been identified for various species (Ott et al. 1966 b; Kincaid et al. 1976b; Hamilton et al. 1979). It is important in making comparisons to realize that the threshold levels are largely dependent on the physical nature and solubility of the $\mathrm{Zn}$ compound.

The quadratic response of liver Fe content to increasing dietary levels of supplemental $\mathrm{ZnO}$ observed in Expt 2 was unexpected. Previous investigations with other species such as rats (Cox \& Harris, 1960; Magee \& Matrone, 1960), swine (Cox \& Hale, 1962) and Japanese quail (Coturnix coturnix japonica) (Hamiliton et al. 1979) have shown that excessive levels of dietary $\mathrm{Zn}$ compounds cause a marked reduction in hepatic $\mathrm{Fe}$ concentration and content. However, the anomalous results obtained for the domestic fowl may be partly explained in terms of the corresponding effects of the different dietary treatments on egg production. The depletion of hepatic Fe content observed for the lower levels of $\mathrm{ZnO}$ inclusion may have been due to the joint effect of a diminished tissue Fe uptake concomitant with a drain of liver $\mathrm{Fe}$ stores associated with egg production. Egg-yolk formation has been shown by Halkett et al. (1958) to draw on the plasma Fe pool in laying hens and, since it has been estimated that a $50 \mathrm{~g}$ egg contains approximately $2.25 \mathrm{mg} \mathrm{Fe}$ (Romanoff \& Romanoff, 1949), it would seem likely that egg production draws heavily on their Fe reserves. The observed increases in liver Fe content for the groups offered the diets with the two highest levels of $\mathrm{ZnO}$ supplementation may therefore reflect the corresponding cessation in egg production induced by these treatments. The resultant effect on the hepatic $\mathrm{Fe}$ content may have been reinforced by the associated depletion of liver $\mathrm{Cu}$ stores since there is evidence that $\mathrm{Fe}$ mobilization is inhibited at low $\mathrm{Cu}$ levels (Butler, 1971).

The slight increase observed in liver $\mathrm{Cu}$ concentration with the high dietary $\mathrm{ZnO}$ treatments of Expt 1 was evidently a reflection of the diminished liver weight since added dietary $\mathrm{ZnO}$ caused a significant depression in total liver $\mathrm{Cu}$ content. The severe reduction in hepatic $\mathrm{Cu}$ levels was even more apparent in Expt 2. The distinct increase in kidney total $\mathrm{Cu}$ content and concentration may reflect an increase in renal excretion of endogenous $\mathrm{Cu}$ associated with the observed antagonistic effect of dietary $\mathrm{ZnO}$ on liver $\mathrm{Cu}$ storage. The fall in the spleen and adrenal Cu concentrations at the $4 \mathrm{~g} \mathrm{Zn} / \mathrm{kg}$ level of supplementation may be attributed to the competitive effect of $\mathrm{Zn}$ and $\mathrm{Cu}$ but there is no obvious explanation for the rise in $\mathrm{Cu}$ concentration of the adrenals after the initial fall at the lowest level of supplementation although this must be a function of treatment.

The effects of excessive dietary $\mathrm{ZnO}$ intake on the storage and utilization of $\mathrm{Cu}$ in the mature fowl have not been investigated by other workers, although the antagonistic effect of dietary $\mathrm{ZnO}$ on tissue $\mathrm{Cu}$ accumulation has been extensively reported for other species including rats (Cox \& Harris, 1960), broiler chicks (Johnson et al. 1962), sheep (Ott et al. $1966 \mathrm{~b}$ ) and turkey poults (Vohra \& Heil, 1969). Furthermore, an inverse correlation between hepatic $\mathrm{Fe}$ and $\mathrm{Cu}$ levels has been identified by Ritchie et al. (1963) in growing pigs as well as by Ott et al. $(1966 b)$ in lambs. The results of the present work suggest that an inverse relation between the liver total $\mathrm{Fe}$ and $\mathrm{Cu}$ contents also exists in adult domestic fowl offered high levels of dietary $\mathrm{ZnO}$. 
The authors thank Mr W. D. Graham and Mrs D. A. Macartney for technical assistance and the British Egg Marketing Board Research and Education Trust for the award of a postgraduate scholarship to S. W. G.

\section{REFERENCES}

Agricultural Research Council (1975). The Nutrient Requirements of Farm Livestock no. 1, Poultry. London: H.M. Stationery Office.

Brake, J., Thaxton, P., Pardue, S. L. \& Morgan, G. W. (1977). Poultry Science 56, 1697-1698 Abstr.

Butler, E. J. (1971). In Physiology and Biochemistry of the Domestic Fowl, pp. 397-426 [D. J. Bell and B. M. Freeman, editors]. London: Academic Press.

Cox, D. H. \& Hale, O. M. (1962). Journal of Nutrition 77, 225 228.

Cox, D. H. \& Harris, D. L. (1960). Journal of Nutrition 70, 514-520.

Creger, C. R. \& Scott, J. T. (1977). Poultry Science 56, 1706 Abstr.

Dewar, W. A., Wight, P. A. L., Pearson, R. A. \& Gentle, M. J. (1983). British Poultry Science 24, $397-404$.

Eltohamy, M. M., Takahara, H. \& Okamato, M. (1980). Journal of the Faculty of Agriculture, Kyushu University 24, 189-199.

Fisher, C., Laursen-Jones, A. P., Hill, K. J. \& Hardy, W. S. (1973). British Poultry Science 14, $55-68$.

Folch, J., Lees, M. \& Sloane Stanley, G. H. (1957). Journal of Biological Chemistry 226, 497-509.

Gentle, M. J., Dewar, W. A., Wight, P. A. L. \& Dick, K. M. (1982). Journal of Intake Research 3, 53-60.

Griminger, P. (1976). In Avian Physiology, 3rd ed., p. 312 [P. D. Sturkie, editor]. New York, Heidelberg and Berlin: Springer-Verlag.

Halkett, J. A. E., Peters, T. \& Ross, J. F. (1958). Journal of Biological Chemistry 231, 189-199.

Hamilton, R. P., Fox, M. R. S., Fry, B. E. Jr, Jones, A. O. L. \& Jacobs, R. M. (1979). Journal of Food Science 44, 738-741.

Hermayer, K. L., Stake, P. E. \& Shippee, R. L. (1977). Poultry Science 56, 1721-1722 Abstr.

Johnson, D., Mehring, A. L., Savino, F. X. \& Titus, H. W. (1962). Poultry Science 41, 311-317.

Kare, M. R. \& Rogers, T. G. (1976). In Avian Physiology, 3rd ed., pp. $29-52$ [P. D. Sturkie, editor]. New York, Heidelberg and Berlin: Springer-Verlag.

Kincaid, R. L., Miller, W. J., Fowler, P. R., Gentry, R. P., Hampton, D. L. \& Neathery, M. W. (1976a). Journal of Dairy Science 59, 1580-1584.

Kincaid, R. L., Miller, W. J., Jensen, L. S., Hampton, D. L., Neathery, M. W. \& Gentry, R. P. (1976b). Poultry Science 53, 1954-1957.

Leveille, G. A. (1969). Comparative Biochemistry and Physiology 23, 431.

Magee, A. C. \& Matrone, G. (1960). Journal of Nutrition 72, 233-242.

Magee, A. C. \& Spahr, S. (1964). Journal of Nutrition 82, 209-216.

Miller, W. J., Clifton, C. M., Fowler, P. R. \& Perkins, H. F. (1965). Journal of Dairy Science 48, $450-453$.

Oh, S. H., Nakave, H., Deagen, J. T., Whanger, P. D. \& Arscott, G. H. (1979). Journal of Nutrition 109, $1720-1729$.

Ott, E. A., Smith, W. H., Harrington, R. B. \& Beeson, W. M. (1966a). Journal of Animal Science 25, 414-418.

Ott, E. A., Smith, W. H., Harrington, R. B., Stob, B. M., Parker H. E. \& Beeson, W. M. (1966b). Journal of Animal Science 25, 424-431.

Palafox, A. L. \& Ho-A, E. (1980). Poultry Science 59, 2024-2028.

Pearce, J. (1971). Biochemical Journal 123, 717-719.

Ritchie, H. D., Leucke, R. W., Baltzer, E. V., Miller, E. R., Ullrey, D. E. \& Hoefer, J. A. (1963). Journal of Nutrition 79, 117-123

Roberson, R. H. \& Schaible, P. J. (1960). Poultry Science 39, 893-896.

Romanoff, A. L. \& Romanoff, A. J. (1949). The Avian Egg, pp. 353-358. New York: John Wiley.

Shippee, R. L., Stake, P. E., Koehn, N. V., Lambert, J. L. \& Simmons, R. W. (1979). Poultry Science 58, $949-954$.

Stevenson, M. H. \& Jackson, N. (1981). British Journal of Nutrition 46, 71-76.

Vohra, P. \& Heil, J. R. (1969). Poultry Science 48, 1686-1691. 